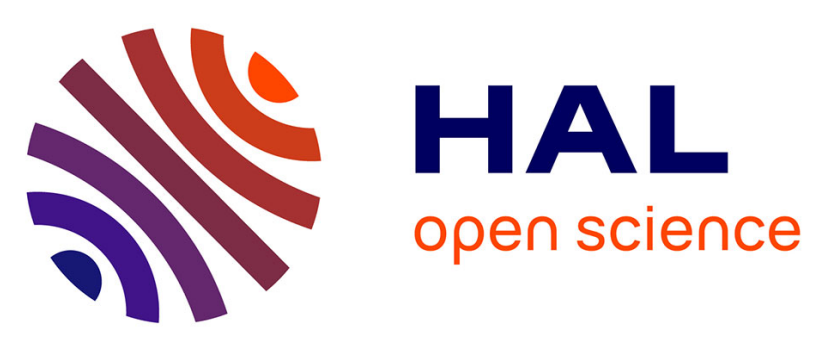

\title{
New City, New Citizens?: A Lefebvrian Exploration of State-Led Housing and Political Identities in Luanda, Angola
}

Chloé Buire

\section{- To cite this version:}

Chloé Buire. New City, New Citizens?: A Lefebvrian Exploration of State-Led Housing and Political Identities in Luanda, Angola. Transformation: Critical Perspectives on Southern Africa, 2017, 93 (1), pp.13 - 40. 10.1353/trn.2017.0001 . hal-01790467

\section{HAL Id: hal-01790467 https://hal.science/hal-01790467}

Submitted on 15 Jul 2019

HAL is a multi-disciplinary open access archive for the deposit and dissemination of scientific research documents, whether they are published or not. The documents may come from teaching and research institutions in France or abroad, or from public or private research centers.
L'archive ouverte pluridisciplinaire HAL, est destinée au dépôt et à la diffusion de documents scientifiques de niveau recherche, publiés ou non, émanant des établissements d'enseignement et de recherche français ou étrangers, des laboratoires publics ou privés. 


\title{
New city, new citizens? A Lefebvrian exploration of state-led housing and political identities in Luanda, Angola
}

\author{
Chloé Buire \\ Les Afriques dans le Monde, CNRS, Pessac, France \\ c.buire@sciencespobordeaux.fr
}

\begin{abstract}
Since its inauguration in 2011, the New City of Kilamba has become one of the most emblematic examples of the Chinese-funded spectacle of reconstruction in post-war Angola. Its tabula rasa urban paradigm has been widely criticised by housing experts in and out of Angola but little is known of its reception by the general population in Luanda. This article retraces the incremental appropriation of Kilamba City by its residents in order to question how the occupation of a new city shapes the relationship between ordinary city-dwellers and the state.

Based on direct observation in Luanda and media monitoring since 2011, the article unveils a multi-faceted reality where residents express at the same time pride and preoccupation, satisfaction and uncertainty. It uses Henri Lefebvre's notion of 'production of space' to suggest that the conundrums of the new city could contribute to the emergence of a democratic moment in Angola.
\end{abstract}

\section{Introduction}

The new city of Kilamba, located about 30 kilometres South of Luanda, is an emblematic case of the oil-for-infrastructure model that characterises post-war reconstruction in Angola since 2002 (Croese 2012, Corkin 2013). Built between 2009 and 2010 by one of the major Chinese state-owned building companies, Kilamba City ${ }^{1}$ has been widely criticised for being a symbol of a development that chooses the fast-paced delivery of physical infrastructures over long-term investments in education and health care and that allows opaque multi-million dollars deals to maintain the oligarchic regime in power (Schubert 2014, Soares de Oliveira 2015).

However, Kilamba City is also an example of the successful 'spectacle of reconstruction' (Soares de Oliveira 2015) orchestrated by the Angolan government. On the streets of Luanda, the achievement is unquestioned. With a unique rent-to-buy scheme, Kilamba and its smaller replicas that are mushrooming across the country represent the most affordable housing opportunities opened to the

\footnotetext{
${ }^{1}$ For the sake of concision, the text will alternatively refer to the new city of Kilamba as Kilamba City or Kilamba.
} 
public in Angola since the end of the socialist era. Less than two weeks after the first public sales in February 2013, more than 18,000 flats had been sold in Luanda (Angonotícias 2013).

Reviewing the reception of the flats by the residents since 2013, this article questions how the sudden occupation of a new city shapes the relationship between ordinary city-dwellers and the state. What idea of citizenship does it produce? What ruptures and continuities can we trace with political identities forged in a long history of conflict and hegemonic domination?

Based on media monitoring since 2011, interviews conducted in Luanda in 2013 and 2015, and the results of an exploratory survey conducted by local researchers in $2014,{ }^{2}$ the article unveils a multifaceted reality where residents express at the same time pride and preoccupation, satisfaction and uncertainty. In order to unravel the numerous contradictions of a success that has been as rapid as it is fragile, the analysis borrows Henri Lefebvre's distinction between three complementary dimensions of space (Lefebvre 1991). In Lefebvre's words, the production of space goes beyond the dichotomy between planning from above and practices from below. It rather lies on a triangular dialectic between the representations of space designed by architects, planners and administrators (the conceived space), the concrete spatial practice performed on the ground by all users (the perceived space), and the abstract values and symbols associated with a particular place (the lived space).

After providing some background information on Kilamba City and explaining more in detail the concept of the production of space, the article proceeds to an analysis of the inherent tensions of each of these dimensions in the case of the new city. By creating an urban system from scratch without touching the existing metropolis, the new city develops a model of tabula rasa urbanism that results in many conundrums, in terms of conception, practices and representations alike. However, the very idea of the production of space is not just meant to ease description. It is the basis of a critical theory of space that leads to the radical concept of 'differential space' where differences and contradictions are seen as productive forces towards the realisation of the right to the city (Lefebvre 1991). The last section of the article will present two examples of these productive tensions in the case of Kilamba. Reading these tensions as symptoms of what Lefebvre calls 'spatial chaos', the article contends that Kilamba City might well be 'the system's Achilles' heel' (Lefebvre 1991:63). The current contradictions of the model of the new city can then be understood as conditions for the emergence of a democratic moment in the construction of post-war Angola.

\footnotetext{
${ }^{2}$ The local NGO Development Workshop, in partnership with the University of Michigan, distributed 178 questionnaires to inhabitants of Kilamba City between July and August 2014 (Croese and Bota 2015, Pitcher 2015).
} 


\section{The production of a new space for the new nation}

As most colonial cities, Luanda inherited a profoundly divided urban fabric where planned infrastructures were limited to the European centre, and that created the basis of the current deficit in affordable housing (Development Workshop 2011, Jenkins et al 2002, Oppenheimer and Raposo 2007, Roque 2011). The housing backlog worsened after independence, with the civil war (1975-2002) provoking a massive influx of displaced people into the capital, feeding a rapid sprawl of spontaneous settlements in the periphery (locally known as musseques) and the densification of central neighbourhoods (see Figure 1).

At the end of the war in 2002, Luanda suffered a situation of chronic overcrowding aggravated by poor urban regulation. At the time, Jenkins, Robson, and Cain (2002:9) estimated that 'probably $75 \%$ of the population live(d) in informal settlement areas or in informal ways within the formal urban areas'. Despite substantial efforts made since then, the housing market remains poorly controlled: there are no mechanisms to call the local government to account; most public works are in the hands of foreign private constructors; and changing land regulation allows widespread corruption (Cain 2013, Development Workshop 2008). 15 years after the end of the war, the population has more than doubled to reach 6.9 million inhabitants (census 2014). UN-Habitat (2014) projects continuous growth for at least another decade, making the housing backlog extremely severe and contributing to what Sogge (2009) has called 'a ticking political bomb'.

In this context, the eruption of a veritable construction boom since the mid-2000s represents hope for ordinary city-dwellers (although often accompanied by fear of displacement) and promises high profits for the construction companies. Most of all it provides the MPLA, former Liberation movement turned authoritarian party-state after independence, with one of the most efficient tools to recast its legitimacy in the new millenium. Soares de Oliveira (2015:66) is unambiguous: 'increasing the housing stock is one of those areas where popular aspirations resonate with MPLA priorities'. However, for de Oliveira, the promise to build one million houses by 2012, strategically announced in the run up to the legislative elections of 2008 was a 'tantalizing commitment'. Croese $(2012,2016)$ is more nuanced and suggests that even if the one million figure was more an imitation of similar programmes launched in the developing world than a realistic projection, the electoral promise reflected the will to build a developmental state. 


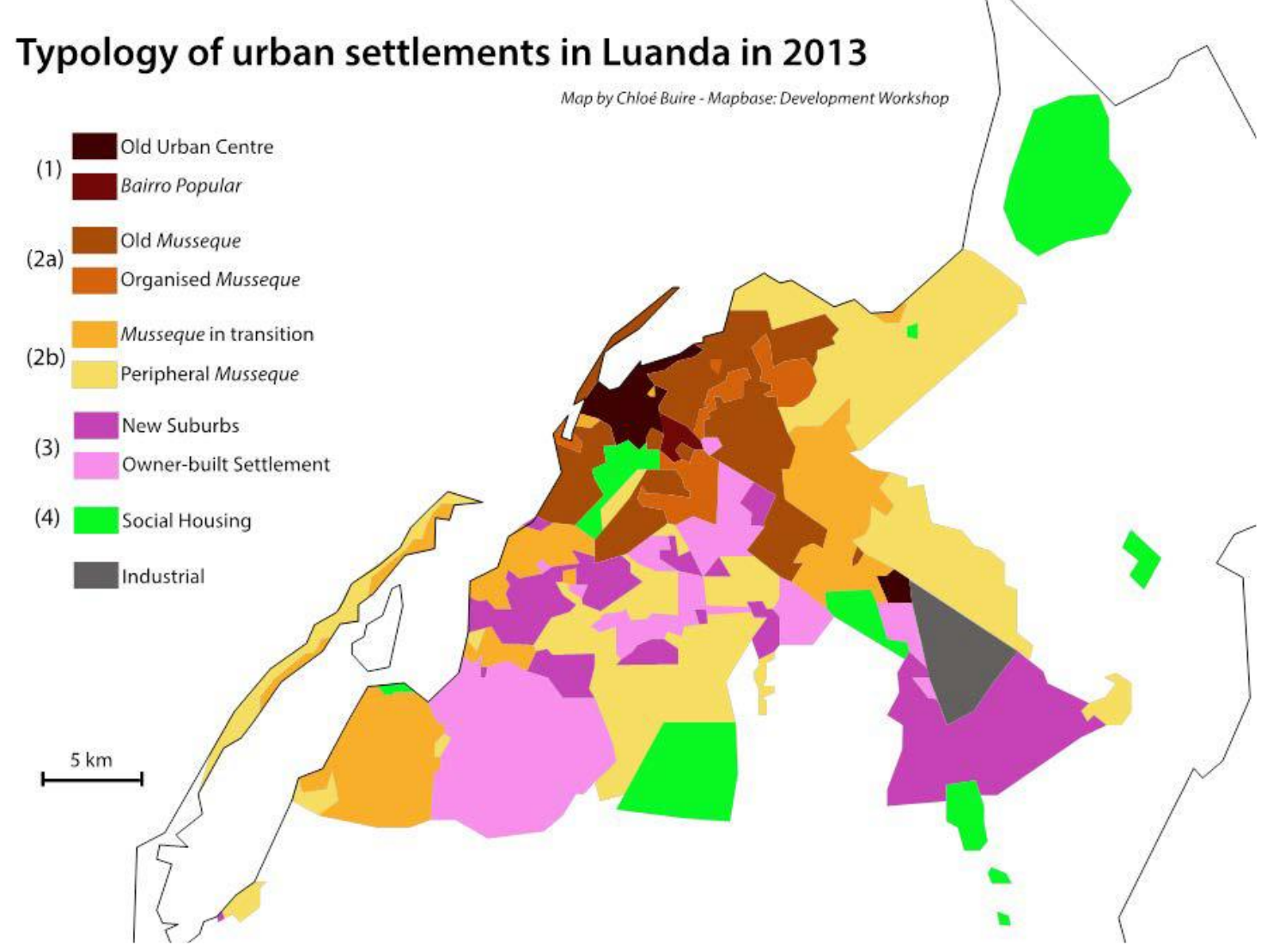

Figure 1: Luanda urban fabric

From forced removals to social housing: emergence of a developmental state

Since the end of the civil war in 2002, the ruling party has developed three types of public housing interventions. Immediately after the war, the government encouraged small-scale site-and-service projects to re-house dwellers living in what were officially marked as 'risk areas' in need of 'emergency relocation'. Many of these involuntary removals were in fact violent evictions sending people to tented camps in the periphery (Amnesty International 2003, 2007).

The growing condemnation by international watchdogs of the displacement started to spread locally in the form of grass-root political contestation (Gastrow 2013, 2014). Fear of seeing the flaws of its developmental approach publicly exposed possibly stimulated the government to develop a more sustainable model of rehousing. Under the designation 'urbanised settlements', the second type of state-led housing consists of rows of semi-detached houses located far outside the urbanised area (Buire 2014, Croese 2012). These settlements were meant to grow incrementally, a few hundred houses at a time, following the rhythm of the forced removals that accompany urban renewal in the city centre. However, the small investments made by the residents in their new houses added up quickly and soon turned these housing projects into new sprawling suburbs that are now part of the metropolis in the 
mind of the residents, despite weak governmental linkages and poor accessibility (Croese 2016, Udelsmann et al 2016).

In the run up to the 2008 elections, public housing eventually took a new dimension. Social housing became the new buzzword in official discourses. ${ }^{3}$ Marketing itself as a developmental state, the government renamed the semi-urbanised peripheries where people had been forcedly removed 'social housing complexes' and launched the construction of what it hoped would be self-sufficient satellite cities across the country (Benazeraf and Alves 2014, Croese 2012). Kilamba City, dubbed 'the jewel in Angola's reconstruction crown' in local media, was intended as the pilot project of this new form of urbanisation that would offer a new lifestyle sheltered from the ills of the congested city (da Rosa 2011, Soares de Oliveira 2015:66-67). As the flagship project of the housing effort of the state, Kilamba illustrates the material and symbolic production of the New Angola.

The multiplication of state-led housing initiatives should not come as a surprise in a country recovering from three decades of civil war. What is more surprising maybe is the fact that these various interventions are not part of a comprehensive plan. What is rhetorically referred to as 'social housing' in Angola is mainly a collection of disparate projects emerging from ill-identified and often unrelated sectors of the state (Croese 2016, Gastrow 2014). These projects nonetheless contribute to the edification of a developmental state. In Henri Lefebvre's theory of space as a social product, they constitute concrete 'means of production' of social and political superstructures. They are the materialisation of the dialectical relationship between the production of urban space and the production of political order.

[Space] is at once a precondition and a result of social superstructures. The state and each of its constituent institutions call for spaces - but spaces which they can then organize according to their specific requirements; so there is no sense in which space can be treated solely as an a priori condition of these institutions and the state which preside over them. (...) Though a product to be used, to be consumed, it is also a means of production. (Lefebvre 1991:85)

\section{The Production of Space: a triad for a critical enquiry of contemporary urbanisation}

Described by David Harvey as an 'intensely political document' (Harvey 1991:431), Lefebvre's The Production of Space offers a critical theory of space. To counter the domination of the technocrats of

\footnotetext{
${ }^{3}$ Reconstituting the institutional framework that supports the development of state-led housing projects in Angola since the end of the war, Croese (2016) notes that the term 'social housing' became ubiquitous in the legislation after 2007, with the adoption of a 'Framework Law on Housing' in September 2007 and the creation of a 'Social Housing Programme' the same year.
} 
his time, Lefebvre distinguishes between the practical experience of everyday life that is both practical and symbolical, and the institutional knowledge produced academically, and the symbolical sphere produced by our individual and collective imagination. He develops a precise and complex vocabulary to unfold these distinct, although complementary, dimensions of social space.

Everyday life is core to Lefebvre's idea of space. He defines the spatial practice of a society as the accumulation of micro-practices that can only be evaluated empirically and that is 'lived directly before it is conceptualized' (1991:34). A combination of 'competence' and 'performance', spatial practice secretes the perceived space (1991:38). Following Lefebvre, this dimension remains largely overlooked, since it escapes the formal rationality of institutional knowledge.

Representations of space on the contrary, is 'the space of scientists, planners, urbanists, technocratic sub-dividers and social engineers' (1991:38). This comes together as a coherent 'code of space' that is 'tied to the relations of production and to the "order" which those relations impose' (1991:33). Visualised through designs, plans and maps, the representations of space constitute the conceived space that tends to dominate the other two dimensions of space.

Lastly, the lived space or representational space is 'linked to the clandestine or underground side of social life' (1991:33). It is a space associated with the images, symbols and values of users and inhabitants. Sometimes described by artists, anthropologists and philosophers, the lived space is that of imagination. When confronted by the representations of space, the lived space is 'dominated' and 'passively experienced' since it cannot be captured through verbal signs (1991:39).

The perceived, the conceived, and the lived eventually constitute what Lefebvre calls $a$ triad of dialectical relationships. At a theoretical level, 'the individual member of a given social group, may move from one to another without confusion' (1991:40). However, as Lefebvre demonstrates, the relationships across the triad are much more complicated in real life. Lefebvre describes how capitalism has historically engendered power relations that impose the conceived above the perceived and the lived. The next section will present the representations of space that dictated the edification of Kilamba City, a social space whose conception has been tightly controlled by the central state.

\section{Kilamba City, implementing a tabula rasa urban paradigm}

Kilamba City is by far the largest housing project delivered by the Angolan state since the end of the war. Financed through Chinese 'oil for infrastructures' loans, designed and built by Chinese contractors under the umbrella of the China International Trust and Investment Corporation (CITIC 2009), Kilamba is also an example of the ' $100 \%$ state financial circuit (from the lending institution and contractors to the off-taker)' that characterises the deals signed between China and Angola since 
2002 (Benazeraf and Alves 2014:2). Although details of these credit lines remain opaque, ${ }^{4}$ a number of impressive (and unverifiable) figures relative to Kilamba circulate widely: the first phase built between 2010 and 2012 supposedly cost 3.5 billion dollars and consists of 710 to 750 buildings totaling about 20,000 flats. Figure 2 provides an indicative timeline of the project.

\begin{abstract}
Figure 2: Kilamba City milestones
2008: Chinese state-owned CITIC group channels the funds of various Chinese investors to the Angolan National Reconstruction Office for the construction of Kilamba City. First stone laid in August.

2009: Adoption of the National Urbanism and Housing Framework that formalises the electoral promise to build 1 million houses before 2012. November 2010: Xi Jinping, China's then vice-president, visits Kilamba's construction site.

July 2011: Inauguration of the new City by president Eduardo dos Santos.

July 2012: Prices of the flats are announced. With units starting at $\$ 120,000$, and in the context of a limited mortgage market, sales are very limited. Kilamba is dubbed a 'ghost city' in international media. February 2013: In order to 'save the prestige project' (Cain $2014: 565)$, prices are dropped to $\$ 70,000$ for the smallest units. The government introduces a rent-to-buy scheme managed by SONIP, a filial of the national oil company (TPA 2013). Two weeks later, SONIP announces that it has sold $72 \%$ of its stock and creates a waiting list (Angonotícias 2013).

August 2014: In response of the growing scandal surrounding the sales in Kilamba, the government transfers the commercialisation to Imogestin. New rules are implemented. June 2015: KK5000, an annex to Kilamba City is opened to the public. New price drop of the flats in Kilamba (Kilamba News 2015). October 2015: Imogestin announces that all installments uncollected by SONIP since 2013 will have to be paid over the next 12 months. Kilamba inhabitants mobilise (see below).

February 2016: Joaquim Israel, president of Kilamba City, announces that the city counts 95,000 inhabitants (O País 2016).

(Sources: Benazeraf and Alves 2014, CAHFA 2013, Rede Angola 2014)
\end{abstract}

The story of Kilamba City is remarkable at various levels. The exceptional role played by China in the project has been widely commented (Croese 2012, Benazeraf and Alves 2014). Soares de Oliveira (2015) and Pitcher and Moorman (2015) insisted on the symbolic importance of the new city for dos Santos regime at the international level. Described as 'a grand initiative that would tackle housing shortage once and for all' by president dos Santos in his inauguration speech (Angop 2011), Kilamba hit the headlines globally, with the declarations of some optimistic visitors, such as Mozambican

\footnotetext{
${ }^{4}$ See the work of investigative journalist Rafael Marques $(2011,2013)$ to get a sense of the collusion of interests between high ranking public officers and the contractors involved in the construction of Kilamba.
} 
president Guebuza who saw in the new city a model for the future of African metropoles (Angonoticias 2011) and many irritated reactions, mainly from Western journalists prompt in condemning the erection of a ghost city (BBC 2012, Le Figaro 2012, Mail\&Guardian 2012).

At the domestic level, the development of a unique subsidised market had a profound effect on the socio-economic fabric of Luanda. Kilamba rent-to-buy scheme created the most affordable new houses available for public sale. Local journalists argued that the new housing stock affected housing values across the city (Angop 2013). In terms of the political economy, the creation of such a massive stateled housing project altered the conditions under which the central state can be held accountable by institutionalising new brokers between the state and the citizens. As I demonstrate below, the realestate companies in charge of Kilamba City (Delta, SONIP, and now Imogestin) represent unprecedented interlocutors to whom ordinary citizens can now address their concerns and complaints. Lastly, what is maybe the most impressive about Kilamba is the consensus it reached amongst the general population. Quite pragmatically, Kilamba City came to embed the urban aspirations of many Angolans for the material lifestyle it made possible. Its fully equipped flats spare the effort of autoconstruction and avoid the over-densification of the musseques. Its parks, sports fields, schools and medical centres (although the buildings are not always staffed adequately) contrast with the usual scenario of un-serviced land slowly consolidating in the periphery. One could also argue that images of the new city were broadcasted so repeatedly on national television, that its modernist aesthetics eventually permeated Angolans' imaginations, but the adhesion to Kilamba runs deeper than mere propaganda (Gastrow 2016). As a young Luandense told me, Kilamba represents the possibility to live the city 'in a different way', even for those who do not live there. In that sense, it has 'reduced the effort to imagine' what modern urban life can be like in Angola (reduziu o esforço de pensar, interview December 11, 2015).

It is important to unravel the implications of this new urban metaphor. The modernist tabula rasa approach of Kilamba carries the idea that the only solution to Luanda's derelict and congested urban reality is a radical rupture, both socially and geographically. Despite the efforts of local architects to defend the importance of the musseques for Angolan urbanity, ${ }^{5}$ the success of the new City eventually dismisses any alternative approaches that would seek to improve the existing fabric. In that sense, Kilamba literally 'reduced (or constrained) the effort' to imagine an urban future.

\footnotetext{
${ }^{5}$ See in particular the work directed by Angela Mingas through the Architecture Forums organised at the Catholic University between 2005 and 2015 .
} 
The fantasy of an urban projection that would develop without dealing with the ills inherited from the past is highly problematic. It fails to acknowledge colonial racism and segregation. It actually reproduces the colonial obsession to eliminate the musseques ${ }^{6}$ and feeds new segregationary tendencies (Udelsmann Rodrigues 2009). Although the tabula rasa paradigm is popular with many African states at the moment, various analysts have highlighted that it is unsustainable in many ways (Croese et al 2016): the societal reasons that led to the degradation of 'the old city' are not addressed in the new one (Udelsmann Rodrigues 2009, Watson 2014), the economic model of state subsidy is impossible to reproduce (Buckley et al 2016), and it potentially annihilates the democratic acceptance of social diversity and agonism (Bhan 2014).

From the political gesture of an electoral promise to the unquestioned success of a new urban product, from the creation of a subsidised market to the dismissal of historical urbanity, Kilamba City eventually constitutes a multifaceted object that defies linear analyses. The theoretical triad of conceived, lived and perceived space developed by Lefebvre is a useful basis to unfold these contradictions, as the rest of the article will now develop.

\section{Conceived, lived, perceived: Kilamba City as a node of contradictions}

Kilamba City provides a fecund empirical basis to put Lefebvre's theory at work. The recent opening of the city to public sales offers an opportunity to observe the production of a social space from scratch in its three dimensions. As a conceived space, Kilamba is a spectacular example of the Sino-Angolan development model, well known for its contradictions and deadlocks. In terms of lived and perceived space, however, examining the social values associated to Kilamba and describing the myriad of practices developed by residents helps to understand Kilamba not only as the product of a specific mode of production of urban space but also as a process of social production in itself.

\section{The conceived space of Kilamba City: limits of the Sino-Angolan development model} Although Corkin (2013) has warned against the western bias leading to simplistic visions of China taking over Africa, the fact that Kilamba stood empty for 18 months after its inauguration fuelled a lot of critiques internationally as well as from Angolan civil society. In September 2012, I witnessed a

\footnotetext{
${ }^{6}$ It is to be noted that colonial master plans promoted the development of satellite cities as early as in 1942 (Fonte 2012 ).
} 
roundtable discussion between the then 'administrator' of Kilamba ${ }^{7}$ and architecture students at a private university in Luanda. The Q \& A session soon turned into a public condemnation of the project. In a heated debate tainted by xenophobia, the students accused Kilamba of being a foreign product, disconnected from their urban culture and architectural traditions. If such critiques largely receded in the public opinion when the prices of the flats dropped and the long-expected rent-to-buy scheme was finally implemented at the beginning of 2013, serious concerns remain regarding the sustainability of the new city.

In terms of architectural longevity, Angola has previous experiences of rapidly-built infrastructures deteriorating as quickly as they were built, or even collapsing before the first occupation (Soares de Oliveira 2015). A resident of Kilamba testified that he had to occupy five different apartments before finding one presenting no visible structural defects (cracks in the wall, water infiltration, ill-fitted ceilings and doorframes, etc). Prominent architects from the Ministry of Construction confessed that they had no insights into the conception of the project at all (personal communication from a local NGO manager). Left entirely to the expertise of Chinese contractors, the new city was built without much monitoring by official civil engineers. The lack of capacity of the Angolan state to later maintain the project was not anticipated. At the time of my fieldwork in 2015, Chinese brokers were still being called in to resolve planning failures in the city, ranging from small domestic needs (geyser, electric installation, etc) to structural defects (blocked sewage, non-functioning elevators, flooded streets).

Building a new city is a technical challenge, and many projects require some adjustment in their first years. However, the gap between the plans elaborated in China and the reality on the ground is particularly wide in the case of Kilamba. Confessing an embarrassing 'lack of coordination' and of anticipation, Joaquim Israel Marques, president of Kilamba, acknowledged in an interview that the city is a work in progress that still needs to be given a social purpose:

Cities are on-going work (As cidades fazem-se), we are in the process of building Kilamba. We built the city in its infrastructure, now we are going to do the rest: [social] services. We are going to give functions, we are going to decide what we want for the city. (Interview in d'Alva 2014)

However, building more schools, medical centres and police stations will not be enough to provide a diversified economy able to employ the majority of the population, estimated at around 95,000 inhabitants at the beginning of 2016. In terms of its conception, Kilamba City reproduces the

\footnotetext{
${ }^{7}$ After some administrative reshuffling, the new City is now managed by a 'president' chosen directly by Eduardo dos Santos. In Kilamba like in the rest of the country, the absence of local elections contributes to the weakness of public accountability and maintains the hegemony of the ruling party on the ground.
} 
shortcomings of a development model that dangerously overlooks social empowerment in the longterm (Schubert 2014, Soares de Oliveira 2015).

\section{The lived space of Kilamba City: the suburban dream of an elusive middle class}

Lefebvre defines the lived space as that which makes 'symbolic use' of physical objects (1991:39). As noted above, Kilamba represents the long-awaited rupture with the musseques. It is associated with abstract notions of 'modernity' and 'orderliness' that each resident defines not only for him or herself but also for the collective, in a context of intense social scrutiny. To Pitcher and Moorman (2015), Kilamba embeds a truly 'modernist project' that ties together modernity and social responsibility and represents a 'phantasmagoria', repackaging socialist promises into dreams of homeownership. In fact, as soon as Kilamba opened its doors, a series of Facebook pages were created, inviting residents to monitor the (mis)use of the new city. ${ }^{8}$ Residents displayed their own righteous behaviours by posting pictures of their finely decorated living rooms and discussed the pride and responsibility of homeownership. They also reported any deviance they observed in Kilamba, taking pictures of clothes hanging outside the designated laundry area or of cars speeding on the road. Joaquim Israel congratulated the residents for their collaboration and commitment to the preservation of the city. To him, social scrutiny is a proof of civility, especially since it comes against the common assumption amongst Angolans 'that people would not be able to live as a community in high buildings' (interview in d'Alva 2014). ${ }^{9}$ This celebration of a self-policing community needs to be further examined.

In his seminal article, Nikolas Rose (1996) explains how the notion of 'community' is used politically to impose a model of self-government. Inspired by the Foucaldian notion of 'governmentality', Rose notes that the promotion of 'the community' implements 'a new relationship between strategies for the government of others and techniques for the government of the self, situated within new relations of mutual obligation' (1996:331). To him, it doesn't matter whether a specific 'community' exists or not, as long as autonomous individuals commit to the preservation of this imagined social group. In Kilamba, as in many other urban projects erected on the African continent in the last decade, the 'community' that serves as a reference for residents and government alike is 'the middle-class' (Dobbs et al 2012, Anrys 2014, Watson 2014). Soares de Oliveira identifies the Angolan 'new middle-class' through its 'material culture, lifestyle and status expectation' rather than through more traditional

\footnotetext{
${ }^{8}$ These observations come from the monitoring of three main Facebook pages over the course of 2013 (creation of the pages), 2014 and 2015 .

${ }^{9}$ See Pepetela (1990) for a historical take on the construction of the stereotypes of the neo-urbanites in Luanda after independence.
} 
indicators such as education and incomes levels (2015:155). Speaking of a middle-class 'agenda', he contends that the social group associated with Kilamba is the result of a concerted effort by the ruling party to engineer a national bourgeoisie loyal to its own political rule.

In this perspective, one understands the importance of a Lefebvrian reading of Kilamba. Not only does the new city enforce a rupture in the conceived space of Luanda (new city versus musseques) - in terms of lived space, it also naturalises this rupture by becoming the urban signifier of the new middle-class. The socio-political values attached to Kilamba play a performative role for Angolan society at large. The question is then less to decide whether the city is effectively catering for a pre-existing middleclass than to acknowledge that the lived space of the new city actively creates such a category. However, the model of a disciplined middle-class conforming to the expectations of the state might well be mere fiction. The research conducted by Croese and Bota (2015) in Kilamba suggests, for example, that many residents do not consider their flats as their own houses. The rent-to-buy scheme does not fulfil their dream of home-ownership and 35 per cent of the respondents declare to owning another house in Luanda. In the questionnaire, some justified that these houses are lawfully let to tenants but in many informal discussions I had in Kilamba, residents explained that they keep a foothold in the old city, so as to stay closer to the centre when necessary. Despite the discourse of order and responsibility, Kilamba does not end the informal housing practices that characterise Luanda's housing market (such as sub-letting and multiple domestic attachments), nor does it fragment extended family networks into nuclear households, despite the general idea associated with the so called 'modern urban middle-class'.

\section{The perceived space of Kilamba: multi-scalar contradictions of a city in the city}

We have seen how as a lived space, Kilamba highlights the performative power as well as the inconsistencies of the idea of the middle-class. The spatial practice of the residents echoes these tensions. Kilamba residents display daily efforts to conform to the lifestyle they think is appropriate for the middle class despite material constraints at various scales.

At the domestic level, all flats share a similar standard-size living room opening onto the same small balcony, but many residents transformed their main room into a veritable reception area, ornamented with double-ceilings and trendy illumination. These financial and emotional investments transform the basic room into a shop-window of their social status. The decoration sometimes includes items symbolising a sense of Angolan identity: a West-African fabric tablecloth, masks hanging on the wall or ebony statues on display. Making a proper modern Angolan home out of a Chinese-designed flat 
implies walking a thin line between breaking away from the musseques and reclaiming a certain national pride. Past the living room however, more compromise has to be made.

In Kilamba as in the rest of the city, water provision is unreliable. Residents hold on to the old practice of stocking water. A bathroom in a Kilamba flat may look like any bathroom in a musseque: a basic shower leaves room for a pile of colourful plastic buckets filled with water in anticipation of the next cut. Another interesting space within the flats is that of the back balcony. Labelled 'laundry' on the original plans, the balcony is used for all the activities usually done in the yard (quintal), a key space of conviviality of the Angolan home. A young mother of two who moved into Kilamba in 2013 detailed to me the benefits of the electric barbecue to grill meat and fish without inconveniencing the neighbours. Relationships with neighbours are indeed an important concern. If at the domestic level, many seem to accept the compromises they have to make, juggling between normativity and improvisation proves to be harder at the scale of the neighbourhood.

Describing the 'heterogeneous "wellspring” of practices, work and everyday orientations' of urban dwellers engaged in an upward social trajectory in Jakarta, Simone and Fauzan (2013:287) speak of the 'conundrums of being middle-class':

While residents did not appreciate overt displays of lewdness, stupidity or arrogance ... there was a professed widespread appreciation for neighbourhoods as a place of theatre, and a theatre that did not necessarily have to play out according to a set script. (Simone and Fauzan 2013:290)

Simone and Fauzan argue that households who share the same aspiration of being middle-class do not follow a uniform trajectory but engage in multiple relationships ranging from overt disdain to pragmatic association. A similar game of fluid cooperation operates in Kilamba. Reflecting on the internal work of the resident committee that he presides over, Claudio, ${ }^{10}$ a resident of Kilamba in his early thirties analyses everyday micropolitics: 'People complain all the time. They are never happy with what I do but when I want to step down they don't want to let me go'. The biggest challenge for Claudio is the collection of the monthly contribution owed by the residents to maintain the shared spaces of the building (entrance hall, stairs, elevators, garden). Claudio acknowledges that AKZ 10,000 is an important addition to the AKZ 45,000 rent ${ }^{11}$ but ensures that it is a minimum to hire reliable

\footnotetext{
${ }^{10}$ Names have been changed.

${ }^{11}$ In 2013, when Claudio first signed his contract, the rent was an equivalent of about US $\$ 450$ (AKZ45,000). Converted at the official rate of April 2016, the current rent amounts to approximately US\$270, an indication of the rapid inflation of the Angolan currency.
} 
cleaning and gardening staff. He immediately adds that the contribution could be cut in half if everyone was actually paying it, suggesting an improvised cross-subsidy system amongst neighbours.

The actual practices of the residents represent Kilamba as a node of contradictions. The display of one's ability to break away from the musseques is constantly constrained by the necessity to retain some survival and cultural practices such as stocking water and grilling fish. The will to live in an orderly environment regimented by well-identified rules comes at odds with the reluctance to financially contribute to its maintenance. In this perspective, the perceived space of Kilamba confirms the 'heterogeneities and conundrums of being middle class' identified by Simone and Fauzan.

\footnotetext{
People look like they are cooperating but in reality they are just acting as if they are doing it in order to win themselves the freedom to do their own thing; or conversely, people may look like they are running all over each other, stabbing each other in the back, pursuing their own strong-willed aspirations when in reality they are implicitly learning from and adjusting to each other, affecting each other without it looking like they are doing so. (2013:291)
}

Eventually the tabula rasa approach adopted for Kilamba leads to tensions at all levels. In terms of conceived space, the lack of coordination between developers and administrators resulted in a management model that remains ill-defined four years after the inauguration. The representational space of Kilamba presents a more productive dynamic, although not less problematic, with the performative idea of an emerging middle class that defines itself through the very enunciation of its existence. In terms of spatial practice, lastly, residents struggle to adopt the lifestyle they anticipate to be right for the kind of people they aspire to be. Each of these tensions promises fecund investigation in the future. However, for Lefebvre a more radical agenda opens if we are to consider how they play out in relation to each other.

At the crossroads between the urbanistic model of new city, the tautological imagination of the middle class and the contradictory spatial practices of the residents, Kilamba eventually interrogates the formation of a new public. In the context of a nation recently coming out of decades of armed conflicts, what does this new social space tell about living together? The last section of this article explores in which measure the new city of Kilamba might reshape the imagination of the state.

\section{The 'strategic hypothesis': a democratic moment for Angola}

The most famous concept associated with Lefebvre's prolific thought is that of right to the city. Mobilised in the Anglophone academic literature through the work of David Harvey and largely popularised around the globe by activists and governments, the concept of right to the city took on a life of its own. While Lefebvre's followers interpret it as a collective right that must be actively claimed 
by civil society, many practitioners rather adopt a reformist approach focusing on a list of individual rights that can be legislated upon by the state (Zérah et al 2011). To avoid the confusion between these two distinct - although not exclusive-approaches, I wish to follow more closely the lexicon developed by Lefebvre in The Production of Space. Scaling up at a more theoretical level, The Production of Space does not speak of a right to the city but rather of a 'right to be different' that is based on 'actual struggles to establish differences' (Lefebvre 1991:64). These struggles, explains Lefebvre, are both theoretical and practical. They aim at 'recaptur[ing] the unity of dissociated elements, breaking down such barriers as that between private and public, and identifying both confluences and oppositions in space that are at present indiscernible' (Lefebvre 1991:64). The description of the three dimensions of Kilamba in the previous section constitutes a necessary step towards the restitution of Lefebvre's radical critique.

\footnotetext{
The combined result of a very strong political hegemony, a surge in the forces of production, and an inadequate control of markets, is a spatial chaos experienced at the most parochial level just as on a worldwide scale. The bourgeoisie and the capitalist system thus experience great difficulty in mastering what is at once their product and the tool of their mastery, namely, space. They find themselves unable to reduce practice (the practico-sensory realm, the body, social-spatial practice) to their abstract space, and hence, new, spatial, contradictions arise and make themselves felt. Might not the spatial chaos engendered by capitalism, despite the power and rationality of the state, turn out to be the system's Achilles' heel? (Lefebvre 1991:63)
}

Although the Marxist references to 'bourgeoisie' and 'capitalism' might sound out of place in the context of Angola's post-socialist, highly centralised political economy, Kilamba offers a perfect example of 'spatial chaos at the most parochial level'. The partnership with China indeed opened a 'surge in the forces of production' that has been entirely captured by the ruling party. Despite this hegemonic control over the conceived space, the previous section has shown how contradictions in the very model of the city, its social values and the spatial practice eventually led to a social space that keeps re-inventing itself and could well be interpreted as 'the system's Achilles' heel'.

The two examples developed below show how the dialectical triad can be interpreted in Kilamba. The first example looks at the contradictions of the rent-to-buy scheme that entered in crisis soon after its implementation. The continuous debates that surround the access to ownership in Kilamba illustrate a situation of spatial chaos. The second example focuses on the possibility of an alternative appropriation of the new city by its residents with the elaboration of a new public sphere on social media. Far from celebrating a radical revolution, these concrete examples contend that the concept of 'differential space' lies not in a once-and-for-all reversal of a specific social order but rather in the constant encroachment of contradictory values and practices that challenge the hegemony. 


\section{Kilamba rent-to-buy controversy as a signal of spatial chaos}

Theoretically, the introduction of a state-subsidised rent-to-buy scheme revolutionised the housing market in Angola. However the application of the scheme on the ground has been a tumultuous succession of attempts rather than a coordinated effort between all stakeholders. Between July 2012 and July 2015, four different institutions have been successively and/or concomitantly responsible for the sales. The flats have firstly been sold directly by the state, either through special schemes benefitting the employees of public ministries or through a limited number of subsidised mortgages via a public fund (the Fundo de Fomento Habitacional). They also served as a token of appreciation for the MPLA's political allies after the national elections of 2012. The government eventually released its rent-to-buy scheme and handed over the sales to Delta, then to SONIP, and finally to Imogestin.

When the scheme was introduced, Kilamba literally became the target of a gold rush. ${ }^{12}$ Aspiring buyers would spend nights on the pavement to have a chance to enter the sales office in the morning. In an attempt to regulate the flow of applications, SONIP closed its doors and started to publish weekly lists in the national daily newspaper. Successful applicants appearing on the list then had to contact the company to sign their contract and receive their keys. But the lull did not last long before a new controversy heated up. In September that same year, SONIP announced that there were more contracts signed than flats available. All three-bedroom flats had been distributed; unlucky applicants would have to top up their payment to buy a four-bedroom instead. In June 2015, 5,400 applicants were still waiting for the flat they had paid for in 2013 (Rede Angola 2015).

In 2014, the saga continued when hundreds of eviction orders were sent to unlawful tenants (Angonotícias 2014, Dos Santos 2014). In some cases, the local administration ruled against the evictions, and chose to wait for the delivery of the second phase of the project in order to regularise everyone. About a hundred evictions did finally happen in October 2014, instilling anxiety into many residents who feared that their contract could be cancelled if an inquisitive audit was to be conducted. Claudio, for example, told me that he bought his application form ( a ficha) from a young man who had no formal position within SONIP. It cost him a few hundred dollars to get the form. Claudio then borrowed money here and there and 'embellished' some salary slips. In total, it took him almost two years to get hold of a title deed. Given the complicated process of the application, many residents, like Claudio cannot be certain that the contract signed after much struggle is legitimate.

\footnotetext{
${ }^{12}$ I have accompanied the series of events described below through media monitoring and participant observation (when I was in Angola). They can be retraced through the excellent press clipping work done by the Angolan NGO Development Workshop. See in particular their 2013 review (Development Workshop CEDOC, 2013).
} 
In September 2015, Imogestin reviewed the scheme once again. Confronted with galloping inflation, the company decided not to index the rent on the actual exchange rate and to maintain the threebedroom flat at AKZ 7 million (estimated around US\$42,000 in April 2016). However, the new sales office inherited from its predecessor a year of uncollected rent. In December 2015, it announced that it would recover the arrears over the next twelve months. Imogestin presented residents with the option of paying in twelve instalments. In practice, this meant that residents would have to pay two rents per month in 2016. It did not take long before a group of residents mobilised against this proposal. Kilamba's latest scandal had burst (O País 2016).

The progressive elaboration of Kilamba's rent-to-buy scheme is a story of cumulative attempts that have not attained any consensus. In December 2015, many residents refused to cover up for what they considered to be SONIP's management incompetency. Others were ready to accept the proposal and thankful for the non-indexation of the prices on the real exchange rate. Those who had bought their flats through the Fundo de Fomento Habitacional or benefitted from a special scheme through their employer were not concerned. And finally, a few residents had already paid for their flats entirely. To summarise the situation in Lefebvrian terms, Kilamba is now close to a state of 'chaos'. The representations of space (the orderly modernist new city) that initially dominated are actively questioned by the residents who do not accept the disconnect with their lived and perceived experience. Acknowledging the contradictions between the three dimensions of space is crucial to envision the possibility of a differential space to emerge, ie an alternative space where multiple voices can be heard and acted upon, rather than a chaotic space where the principles that dominated the initial conception persistently silence dissent. The next section looks at a specific example where a resident experienced such a differential space.

\section{'If it was not for the critical voices...', a new sense of entitlement and agency}

On December 8, 2015, heavy rains fell on Luanda. Not exceptional in this season, the rains flooded the musseques, where residents have long learnt to keep domestic appliances off the floor and to dig temporary drainage channels in the muddy streets. In Kilamba however, residents are not resigned to planning inefficiency yet. Annoyed with the situation in his neighbourhood, Joao, posted on Facebook a series of pictures taken in KK5000, the annex recently built next to Kilamba City. The pictures show accumulated waste overflowing on the pavement and a heavily flooded street (Figure 3a). Two days later, Joao posted a second picture (Figure 3b) accompanied by the caption translated below: 
for everyone to see clearly. I had more than 20 thousand views. And it worked! The video went so far that they took all the water out with an industrial pump in less than 48 hours. This morning, on my way to work, I went there and it had already all dried out, and not only: there were also Chinese and Portuguese engineers and state representatives studying the situation to see how to avoid such flood in the future. They wore suits and ties, I couldn't take pictures, that would have been disrespectful, but I stayed at a good distance and I took a picture just for the neighbours to see that if it was not for the critical voices, maybe no one would be there to solve the problem. Now, let's wait for the next rains... (Adapted from a Facebook post, 10/12/2015)

I argue that these pictures signal the emergence of a micro differential space. In terms of representational space, Joao acted upon a universal value of civic responsibility: although he was not directly affected by the flood, he felt responsible to report on the situation. This position departs from the caricature of individualistic middle-class homeowners solely concerned with their private property. In terms of spatial practice, Joao drove through the flooded street. By doing so, he enacted a practical sense of entitlement to explore his environment and resisted the constraints of planning (in this case bad planning). Finally Joao's comment highlights what a differential space might look like in Kilamba. Joao bases his legitimacy to speak out on the fact that he is a resident of Kilamba. This might seem very mundane at a time where principles of public participation are widespread in good governance manuals, but in Angola decades of colonial dictatorship and authoritarian socialism have built a profound 'culture of fear', that muzzles the expression of personal opinions in public (Schubert 2014). As Joao explains, much deference still goes to those who wear 'suits and ties'. His self-imposed distance when he saw the professionals is an indication of the spontaneous shrinking of an ordinary Angolan citizen in front of anyone identified as a foreign expert or a state representative. Producing a differential space in Luanda thus implies putting an end to the exaggerated deference given to the 'conceivers' of space. It requires city-dwellers to overcome a certain self-deprecation, and to build a sense of entitlement that will allow them to voice out their critical concerns. 


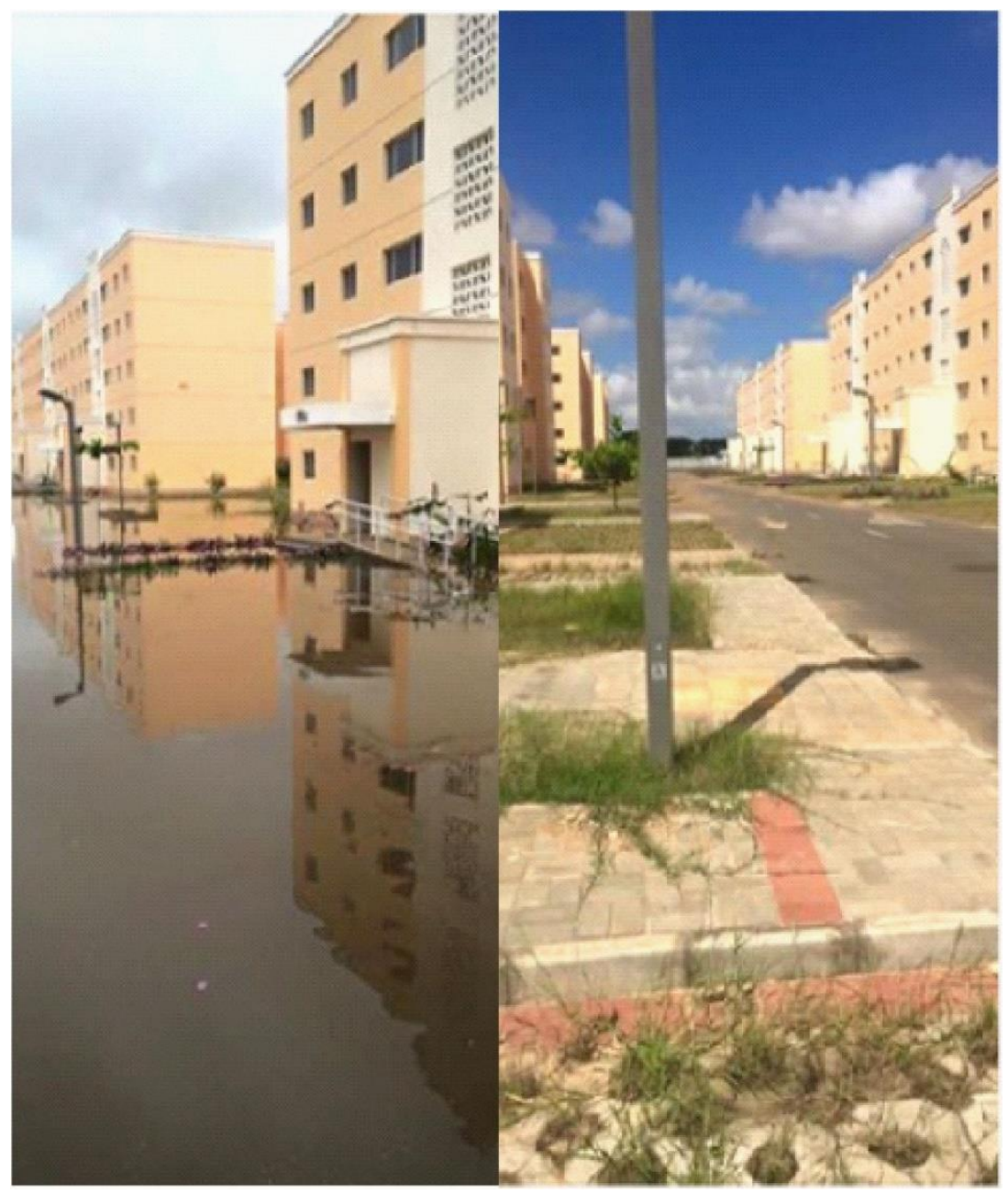

Figure 3: Example of the production of a 'differential space' on Facebook

Figure 3a: Denouncing the flood. Figure 3b: Celebrating the intervention of the engineers and state representatives

In Lefebvrian terms, this means revising the relationship within the triad. Joao's message could be reformulated as follow: 'Our spatial practice as residents of Kilamba can alter the representations of planners if we acknowledge that critiques can be voiced!' This is a basic call to include direct democracy as a value of the lived space. Of course, some neighbours criticised Joao once again, saying that the intervention of the planners had nothing to do with his video. But what matters here is the shift in the triangular dialectic between the perceived, the conceived, and the lived. Joao did not revolutionise urban management but he envisioned a sense of accountability that does not exist in the musseques.

Of course, one post on Facebook is not a socio-political overhaul. Kilamba remains a highly controlled space. Any physical alteration of the flats is strictly regulated, the latest revision of the rent-to-buy scheme was still done without consulting the public, and more generally, the long-term benefits of a 
so-called social housing project where flats are sold for thousands of US dollars remain highly controversial. However, the existence of a forum where residents can disagree with each other and with the state is new in Angola. In 2015 alone, three major crackdowns on civil society reminded that the Angolan state resorts to raw repression of oppositional voices. In April, the police raided the camp of a Christian sect known for its anti-governmental sermons, killing at least 13 civilians (human rights groups reported much higher figures). In May, renowned human rights activist Rafael Marques was sentenced for 'slander' for a book investigating diamond mining in the East of Angola. In June, 15 young activists were arrested and accused of plotting a coup against the president for facilitating an informal book club discussing principles of non-violence. In this context, the fact that residents of Kilamba seize on social media to protest against the management of their city suggests that cracks emerge in what Gramsci called the 'spontaneous consent' of the masses.

\section{Cracks in the fabrication of 'spontaneous consent'}

Gramsci established that 'the apparatus of state coercive power', as illustrated in the three cases of suppressed civil society groups briefly mentioned above, is only one facet of political domination (1971:145). Distinguishing direct domination 'exercised through the State and "juridical” government' from hegemony 'which the dominant group exercises throughout society', Gramsci famously described 'the "spontaneous" consent given by the great masses of the population to the general direction imposed on social life by the dominant fundamental group' (1971:145). In other words, there can be no domination without the actual consent of the population. Besides its capacity to control the world of material production, the dominant group benefits from a historical prestige that gives it the confidence to be on top of the masses.

I argue that the small-scale mobilisation of residents in Kilamba contributes to the erosion of the prestige and confidence of the dominant group. Joao challenged the deference owed to planners. The residents who mobilised against the double-rent system planned by Imogestin threaten the confidence of those who, until recently, had shaped the conceived space of Kilamba without encountering any resistance. Compared to the approach of its predecessors, Imogestin might show signs of adaptation to the claims of the public. The document presenting the revised payment scheme for 2016 emphasised citizenship over technocracy. In February 2016, the residents were invited to voice their concerns during the official visit of Kilamba's president and Luanda's provincial governor (O País 2016). As Joao wishes to believe, the struggle of the residents might have some dialectical effects on the way planners and administrators engage with the citizenry, even if it is still far to produce the kind of multiplicity Lefebvre called for. 


\section{Conclusion: ambiguities of a democratic moment in an authoritarian culture}

While Kilamba City was quickly accepted as a paradigmatic example of the growing presence of China in Africa, the actual fate of Angola's largest new city remains overlooked. This article hopes to contribute to a better understanding of this model of urbanisation, not only in terms of its conception but also in terms of the experience of the residents who invest materially and socially in their new living environment.

Lefebvre's triad helps to identify multi-layered contradictions. By selecting those who can afford a monthly rent of US\$ 300 to US\$ 600, Kilamba certainly contributes to a new social stratification of Luanda. However, the definition of this new middle-class remains highly controversial. Residents' spatial practices and social values show links with the old musseques that conflict with the idea of tabula rasa urbanisation.

These contradictions eventually allow for a political interpretation of Kilamba City. Adopting Lefebvre's 'strategic hypothesis', the article suggests that the spatial chaos that is currently emerging in Kilamba could indicate the opening of a democratic moment for Angola. The idea of the middleclass that Soares de Oliveira described as a 'political agenda' in the hands of the oligarchy might prove more difficult to control than expected. As residents gain confidence in their entitlement to a democratic environment, the historic prestige of those in power diminishes and the tumultuous trajectory of the new city becomes an example of how differential spaces can be crafted within Angolan hegemonic society. True to Lefebvre's dialectical understanding of the production of space, Kilamba City might then become a site of democratic claims. It remains to be seen how successful these claims may be in the longer term and whether what happens in the new city has a potential to reach out in the Angolan society at large.

\section{References}

Amnesty International (2003) Angola. Expulsões forçadas em massa em Luanda. London: Amnesty International.

Amnesty International (2007) Angola: Vidas em ruinas: expulsões forçadas continuam. London: Amnesty International.

Angonotícias (2011) 'Construção da Cidade do Kilamba deve inspirar os Estados da região', newspaper article, August 19. 
Angonotícias (2013) 'SONIP vendeu 18.089 habitações nas centralidades em 15 dias', newspaper article, February 26.

Angonotícias (2014) 'Ordens de despejo contra moradores do Kilamba’, newspaper article,

March 5.

Angop (2011) 'Discurso na inauguração da Cidade Kilamba', newspaper article, July 11.

Angop (2013) 'Mercado imobiliário informal com queda de preços na Ingombota', newspaper article, July 17.

Anrys, S (2014) 'De Afrikaanse baksteenboom gewikt en gewogen' $M O^{*}$. Online at: https://www.mo.be/analyse/hoe-denken-experts-over-afrikaanse-baksteenboom [archive]

$B B C$ (2012) 'Footage shows African "ghost town”", newspaper article, July 2.

Benazeraf, D and A Alves (2014) 'Oil for Housing': Chinese-built New Towns in Angola, Policy Briefing 88, Johannesburg: SAAIA.

Bhan, G (2014) 'The real lives of urban fantasies', Environment and Urbanization 26(1).

Buckley, R, A Kallergis and L Wainer (2016) 'The emergence of large-scale housing programs: beyond a public finance perspective', Habitat International 54(3).

Buire, C (2014) 'The dream and the ordinary: an ethnographic investigation of suburbanisation in Luanda', African Studies 73(2).

Cain, A (2013) 'Luanda's post-war land markets: reducing poverty by promoting inclusion', Urban Forum 24.

Cain, A (2014) 'African urban fantasies: past lessons and emerging realities', Environment and Urbanization 26(2).

CAHFA (2013) 2013 Housing Finance in Africa. Johannesburg: Centre for Affordable Housing Finance in Africa.

CITIC (2009) ‘Angola social housing project—project overview’. Online at: http://www.cici.citic.com/iwcm/null/null/ns:LHQ6LGY6LGM6MmM5NDgyOTYyMDEzNmIwMz AxMjAxMzdlYzA1YTAwMDEscDosYTosbTo=/show.vsml [archive]

Corkin, L (2013) Uncovering African Agency: Angola management of China credit lines. Farnhamt/Burlington: Ashgate Pub Co.

Croese, S (2012) 'One million houses? Chinese engagement in Angola's national reconstruction', in M Power and A Alves (eds) China \& Angola: a marriage of convenience? Cape Town, Dakar, Nairobi and Oxford: Pambazuka Press. 
Croese, S (2016) 'State-led housing delivery as an instrument of developmental patrimonialism: the case of post-war Angola', African Affairs 116(462).

Croese, S and M Bota (2015) 'Projectos habitacionais em Luanda'. Fieldwork Report, presented in Luanda, May 6.

Croese, S, L Cirolia and N Graham (2016) 'Towards Habitat III: confronting the disjuncture between global policy and local practice on Africa's "challenge of slums", Habitat International 53.

D’Alva, A (2014) ‘Uma cidade mais voltada para as pessoas', newspaper article, April 1.

Da Rosa, K (2011) 'Fazer da cidade de Luanda uma das mais belas do mundo', Sonangol Noticias (24).

Development Workshop (2008) Peri-urban Informal Rental Housing Market in Luanda. Luanda: Development Workshop.

Development Workshop (2011) Poverty and Environmental Vulnerability in Angola's Growing Slums: comparative analysis of Luanda, Huambo and Cachiungo. Luanda: Development Workshop.

Development Workshop CEDOC (2013) Dossier Habitação 2013. Online at: http://www.housingfinanceafrica.org/wp-content/uploads/2015/11/Dossier-Habitação-2013.pdf https://www.angonet.org/dw/sites/default/files/online_lib_files/dossier_habitacao_2013.pdf [archive]

Dobbs, R, J Remes, J Manyika, C Roxburgh, S Smit, and F Schaer (2012) Urban World: cities and the rise of the consuming class. San Francisco: McKinsey Global Institute.

Dos Santos, D (2014) Ordens de despejo contra moradores do Kilamba, newspaper article, Jornal de Angola, April 3.

Fonte, M (2012) Urbanismo E Arquitetura Em Angola: De Norton de Matos à revoluite. Casal de Cambra: Caleidoscorton.

Gastrow, C (2013) “"Vamos construir!”: revendications foncières et géographie du pouvoir à Luanda, Angola', Politique Africaine (4).

Gastrow, C (2014) 'Negotiated settlements: housing and the aesthetics of citizenship in Luanda, Angola'. PhD Thesis, University of Chicago.

Gastrow, C (2016) 'Urban redevelopment and political belonging in Luanda, Angola: aesthetic dissent', Antipode. Online at https://doi.org/10.1111/anti.12276.

Gramsci, A (1971) Selections from Prison Notebooks. London: Lawrence and Wishart. 
Harvey, D (1991) 'Afterword', in H Lefebvre, The Production of Space. Oxford/Cambridge: Blackwell.

Jenkins, P, P Robson and A Cain (2002) Luanda City Profile. Luanda: Development Workshop.

Kilamba News (2015) 'KK5000 já tem 'moradores', newspaper article, June 25.

Le Figaro (2012) 'En Angola, la ville fantôme bâtie par la Chine', newspaper article, July 5.

Lefebvre, H (1991) The Production of Space. Oxford/Cambridge: Blackwell.

Mail\&Guardian (2012) 'Angola’s trophy city a "ghost town”", November 23.

Marques, R (2011) 'Kopelipa e Manuel Vicente-Os vendedores de casas sociais'. Online at: http://www.club-k.net/index.php?option=com_content\&view=article\&id=8964:kopelipa-emanuel-vicente-os-vendedores-de-casas-sociais-rafaelmarques \&catid=9\&Itemid $=1078 \&$ lang $=$ pt $[$ archive $]$

Marques, R (2013) ‘The Ill-Gotten Gains behind Angola’s Kilamba Housing Development'. Online at: http://pambazuka.org/en/category/features/77070 [archive]

O País (2016) 'Moradores das centralidades queixam-se ao governador', newspaper article, February 24.

Oppenheimer, J and I Raposo (eds) (2007) Subúrbios de Luanda e Maputo. Lisbon: Colibri.

Pepetela (1990) Luandando. Luanda: Elf Aquitaine Angola.

Pitcher, A (2015) 'Public goods distribution in Africa: the relationship between housing provision and broader government policies'. Conference Paper, Luanda, December 7.

Pitcher, A and M Moorman (2015) 'City building in post-conflict, post-socialist Luanda: burying the past with phantasmagorias of the future', African Cities Reader III.

Rede Angola (2014) 'Linha do tempo da centralidade Kilamba', newspaper article, May 2.

Rede Angola (2015) 'Entrega de casas nas centralidades começa dia 25', newspaper article, June 16.

Roque, S (2011) 'Cidade and bairro: classification, constitution and experience of urban space in Angola', Social Dynamics 37(3).

Rose, N (1996) 'The death of the social? Re-figuring the territory of government', Economy and Society 25(3).

Schubert, J (2014) "Working the system": affect, amnesia and the aesthetics of power in the "New Angola"،. PhD Thesis, University of Edinburgh.

Simone, A and AU Fauzan (2013) 'On the way to being middle class: the practices of emergence in Jakarta', City 17(3). 
Soares de Oliveira, R (2015) Magnificent and Beggar Land: Angola since the civil war. London: Hurst Publishers.

Sogge, D (2009) 'Angola "Failed” yet "Successful”“, Working Paper No. 81, Fride.

TPA (2013) ‘Aquisição de casas nas novas centralidades', newspaper article, February 7.

Udelsmann Rodrigues, C (2009) 'Angolan cities: urban (re)segregation?', in P Nugent (ed) African Cities: competing claims on urban spaces. Leiden: Brill.

Udelsmann Rodrigues, C and S Frias (2016) 'Between the city lights and the shade of exclusion: postwar accelerated urban transformation of Luanda, Angola', Urban Forum 27(2).

UN-Habitat (2014) The State of African Cities 2014: re-imagining sustainable urban transitions. Nairobi: UN-Habitat.

Watson, V (2014) 'African urban fantasies: dreams or nightmares?', Environment and Urbanization 26(1).

Zérah, M-H, V Dupont and S Tawa Lama-Rewal (2011) Urban Policies and the Right to the City in India. Rights, responsibilities and citizenship. New Delhi: UNESCO / CSH. 